STUDIA EDUKACYJNE NR 50/2018

\author{
MARIUSz DEMBIŃSKI \\ Uniwersytet Adama Mickiewicza \\ $w$ Poznaniu
}

\title{
USTAWA 2.0 W PRAKSEOLOGICZNYM PROJEKCIE USTANAWIANEJ RZECZYWISTOŚCI
}

\begin{abstract}
Dembiński Mariusz, Ustawa 2.0 w prakseologicznym projekcie ustanawianej rzeczywistości [Poland's 2.0 Law on Higher Education in the Praxeological Project of a Created Reality]. Studia Edukacyjne nr 50, 2018, Poznań 2018, pp. 197-212. Adam Mickiewicz University Press. ISSN 1233-6688. DOI: $10.14746 /$ se. 2018.50 .13
\end{abstract}

The 2.0 law has come into force. However, its effects will be determined by the methods of its implementation by the staff of the Ministry of Science and Higher Education, the authorities of Higher Education Institutions in Poland and academics dealing with science and arts. Achieving a consensus that satisfies all parties requires cooperation, openness to others, as well as work on the development of cooperation itself. The aim of the article is to emphasize the development of cooperation, which, according to the author, should be conditioned by "research in action". Therefore, drawing attention to the elements of this structure, taking into account the "historical consciousness", embedding these activities in the phronesis and developing the forms of understanding included in it, should be the foundations of an interpretation of the 2.0 law. However, the interpretation of this law will prove more friendly (useful) for the interested parties themselves, if the research in action will take into account the general idea of praxis.

Key words: Act 2.0, research in action, phronesis, understanding, praxis

Ustawa 2.0 została wdrożona w życie, toteż jej błędy, treściowe niedopracowania, czy sprzeczne niuanse zostaną wchłonięte przez systemy zarządzania instytucjami naukowymi, co sprawi, że wiele problemów nurtujących uczonych będzie podlegać dezaktualizacji. Jednak najważniejsze w tym przypadku powinno okazać się, w jaki sposób akt wcielenia tej Ustawy w życie przełoży się na kształtowanie świadomości społeczno-kulturowej społeczności akademickiej oraz w jakiej rzeczywistości przyjdzie im funkcjonować w wyniku zwrotnego ukształcania treści relacji między instytucjami naukowymi a zależnymi od nich podmiotami? Pytając zatem o zmiany dotyczące funkcjonowania podmiotów, jak i instytucji w obliczu tej Ustawy, można 
dwuznacznie stwierdzić, że środki nacisku poparte rzeczową argumentacją staną się - mówiąc językiem Martina Heideggera ${ }^{1}$ - poręczną rękojmią urzeczywistniającą prawdę bycia, prawdę bycia tej Ustawy. Każdy bowiem akt prawny wprowadzający zmianę jest dyktatem wobec tego, co już ustanowione i dlatego będzie budzić zastrzeżenia części zainteresowanych i tym samym przynaglać ich do określonych reakcji ${ }^{2}$. W tym kontekście kwestią nader istotną okaże się, co w takim razie będzie oferować się uczestnikom projektowanej zmiany oraz $\mathrm{w}$ jaki sposób będzie się praktycznie (praxis) urzeczywistniać jej społeczną debatę? Mając zatem w tym przypadku na uwadze pozytywne efekty wynikające $\mathrm{z}$ realizacji tej Ustawy, nie bez znaczenia okaże się jej rozumiejąca realizacja, w obszarze której powinno uwzględnić się ideę badań w działaniu, w ramach których Ustawa 2.0, powinna być traktowana jako projekt organizujący życie naukowe w instytucjach, w których warto uwzględnić ideę ogólnoludzkiej praxis. Powyższe wytyczne ustanawiają wstępnie treści prowadzonych tutaj rozważań.

Mając obecnie już na względzie nieco szerszy aspekt wstępnych przemyśleń, warto zauważyć, iż efektywność realizacji Ustawy 2.0, będzie w dużej mierze zależna od jej wykładni. Oznacza to, że powinno w pierwszym rzędzie odnieść się do badań w działaniu, aby w sposób zwrotny dopracowywać jej organizacyjną strukturę. Warto również odwołać się do poglądów George-Hansa Gadamera ${ }^{3}$, dotyczących „efektywnodziejowej świadomości”, a przy tym również do różnych form ludzkiego działania, wskazanych przez Arystotelesa, by uwzględnić w tej Ustawie pojęcie phronesis. I w końcu, o czym była już mowa, należy zwrócić się do idei ogólnoludzkiej praxis, opracowanej od strony pedagogicznej przez Dietricha Bennera ${ }^{4}$. Całość zespolonej tutaj wykładni Ustawy 2.0 zostanie dopełniona moją propozycją zasad myślenia i działania w płaszczyźnie koegzystencjalnej struktury praxis. W tym miejscu należy, niejako w kontekście poglądów D. Bennera, sformułować hipotezę, iż Ustawa 2.0, podporządkowana strukturze ogólnoludzkiej praxis, na którą składają się takie formy koegzystencjalnego wspólistnienia, jak: polityka, ekonomia, etyka, estetyka, religia i pedagogika, będzie spełniać społeczne oczekiwania, jeżeli nie dopuści się do zdominowania przez którąś z jej form koegzystencjalnych, pozostałych.

Przystępując do dookreślenia wykładni Ustawy 2.0, zaczniemy od wprowadzenia informacji na temat badań w działaniu, które - co warto podkreślić

\footnotetext{
${ }^{1}$ M. Heidegger, Bycie i czas, przekł. B. Baran, Warszawa 1994.

${ }^{2}$ G. Sharp, Od dyktatury do demokracji. Drogi do wolności, przekł. A. Karolak, Warszawa 2013.

${ }^{3}$ H.-G. Gadamer, Practical Philosophy as a Model of the Human Science, Research in Phenomenology, 1980, 9.

${ }^{4}$ D. Benner, Pedagogika ogólna: Wprowadzenie do myślenia i działania pedagogicznego w ujęciu systemowym i historyczno-problemowym, przekł. D. Stępkowski, Warszawa 2015.
} 
- zostały zdefiniowane na wiele sposobów. W tym miejscu odwołamy się do propozycji Stephena Kemmisa i Robina McTaggarta ${ }^{5}$, którzy wyróżnili w nich trzy podstawowe składowe: praktykę, rozumienie i miejsce (sytuację). Tego typu działania mają charakter kolektywny i autorefleksyjny. Wilfred Carr ${ }^{6}$ dodaje, że są one nastawione na dialog i uwikłane historycznie w przedsądy, których prawda podlega uprzedzeniom, co pozwala osiągnąć, jak twierdzi G.H. Gadamer 7 , tak zwaną „świadomość efektywnodziejową”. Zebrane w tym miejscu informacje naznaczają istotę tej Ustawy takimi kategoriami (praktyka, rozumienie, sytuacja, dialog, dzieje, autorefleksja, przedsądy), których praktyczna osnowa powinna podnosić i kształtować świadomość prowadzonych dialogów oraz tym samym przekładać się na jej dziejową efektywność.

W jaki sposób osiągnąć oczekiwany stan? Jeżeli chodzi o pierwszą składową badań w działaniu, czyli praktykę, to należy ją rozumieć - jak pisze Stephen Kemmis:

... jako nawykowe i zwyczajowe działanie, ale oznacza również „wykonywanie czynności", a odwołując się do jej greckich źródeł w pojęciu praxis, oznacza „świadome i zaangażowane działanie" 8 . Praktyka w swoim wykonaniu, performatywnym wykonaniu powinna być czymś naturalnym, czymś przenikniętym zaangażowaniem i jego świadomością. Z kolei naturalność i świadomość prowadzą do refleksji, a więc do pewnego stanu krytycznego podejścia do tego, co się robi, toteż praktyka staje się stosowna, racjonalna i rozważna'.

Osiągnięcie powyższego stanu oglądu czy praktycznego wglądu w sytuację, w której dopełniałaby się ta Ustawa, pozwala zrealizować wyznaczone przez współuczestników debaty dialogu cele, jeżeli ich prawda, a więc i troska o autentyczność oraz odpowiedzialność za jej moralne wdrażanie, będą idąc tropem Jurgena Habermasa ${ }^{10}$ - podlegać badaniom ukierunkowanym na uprawomocnianie twierdzeń w działaniu komunikacyjnym, nastawianym na wzajemne porozumienie zainteresowanych i wypracowanie wspólnego konsensusu. Chodzi głównie o to, jak piszą Svetlana Cicmil i Hugo Gaggiotti ${ }^{11}$,

5 S. Kemmis, R. McTaggart, The Action Research Planner, Geelong 1988.

${ }^{6}$ W. Carr, Filozofia, metodologia i badania w działaniu, przekł. K. Liszka, [w:] Badania w działaniu. Pedagogika i antropologia zaangażowane, red. H. Červinkowá, B.D. Gołębniak, Wrocław 2010, s. $29-44$.

7 H.-G. Gadamer, Prawda i metoda. Zarys hermeneutyki filozoficznej, przekł. B. Baran, Warszawa 2004. s. 410.

${ }^{8}$ S. Kemmis, Teoria krytyczna i uczestniczace badania w działaniu, przekł. K. Liszka, [w:] Badania w działaniu, s. 49.

9 Tamże, s. 50.

10 J. Habermas, Filozoficzny dyskurs nowoczesności, przekł. M. Łukaszewicz, Kraków 2005.

11 S. Cicmil, H. Gaggiotti, Who cares about project deadlines? a processual relational perspective on problems with information sharing in project environments, International Journal of Knowledge Management Studies, 2009, 3, 3-4, s. 222-240. 
iż w przypadku realizacji różnych projektów, ważne okazują się prace uczonych mające na celu kształtowanie postaw ich orędowników i kreatorów, które w swojej odpowiedzialności za jej efekty powinny charakteryzować się otwartością na współpracę w osnowie powagi i szacunku. Zbliżając się zatem do teorii dyskursu J. Habermasa ${ }^{12}$, z której wynika, że praktyki podległe wła$\mathrm{dzy}$, to jest zależne od partii politycznych sprawujących rządy, nie osiągną zamierzonych celów, jeżeli przy ich wdrażaniu nie będzie współpracować się z nastawieniem uwzględniającym zróżnicowane interesy poznania i samostanowienia różnych grup, organizacji i instytucji.

Praktyka badań w działaniu jest zatem tą składową, która prowadzi do jej kolejnego elementu, czyli rozumienia. Wartość i sens tej kategorii są z kolei zwrotnie zależne od efektów badania własnej praktyki, sprowadzonej tutaj do praxis (cel jest ukierunkowany na własne działanie), uwikłanej sytuacyj$n^{13}{ }^{13}$ (trzeci element składowy badań $\mathrm{w}$ działaniu) $\mathrm{w}$ proces realizacji - $\mathrm{w}$ tym przypadku - Ustawy 2.0. Proces ten, co wydaje się oczywiste, w swojej dialogicznej formule ma charakter i indywidualny, i kolektywny, a w swojej praktyce jest zawsze nastawiony na zmiany - zmiany przekonan, idei, wartości, czy postaw ${ }^{14}$. Zrozumienie, a tym bardziej zrozumienie własnej praxis w kontekście konkretnej sytuacji musi domagać się uwzględnienia szerszej jej idei i dlatego odwołuję się do ogólnoludzkiej praxis ${ }^{15}$ - o czym piszę dalej. Dlatego, właściwe zrozumienie konkretnej sytuacji praxis (Ustawy 2.0) wymaga uwzględnienia działań jednostek, jak i dziania się dziejów w tej sytuacji. Oznacza to w konsekwencji, że

Świadomość uczestników jest zatem ukształtowana przez świadomość historyczną lokalne, partykularne oraz bardziej powszechne tradycje, kultury, dyskursy i sposoby życia, które ich poprzedzają ${ }^{16}$.

Zrozumienie własnej praktyki domaga się zrozumienia swoich ograniczeń, uprzedzeń, a w konsekwencji i perspektywy historycznej, które kreują istotę rozumienia. Toteż rozumienie własnego rozumienia staje się możliwe poprzez refleksyjne uczestniczenie $\mathrm{w}$ praktyce/praktykach społecznych. To one umożliwiają osiągnięcie takiego stanu samoświadomości historycznej, który G.-H. Gadamer określa jako „efektywnodziejową świadomość”. To po-

12 J. Habermas, Teoria działania komunikacyjnego, t. 1, przekł. A.M. Kaniowski, Warszawa 1999; tenże, Teoria działania komunikacyjnego, t. 2, przekł. A.M. Kaniowski, Warszawa 2002; tenże, Faktyczność i obowiązywanie. Teoria dyskursu wobec zagadnień prawa i demokratycznego państwa prawnego, przekł. A. Romaniuk, Warszawa 2005.

13 S. Kemmis, Teoria krytyczna, s. 51.

14 Tamże, s. 51-52.

15 Ten szerszy kontekst praxis uwikłany jest w horyzont dziejowy i w tej płaszczyźnie przynależy do działających podmiotów.

16 S. Kemmis, Teoria krytyczna, s. 52. 
przez zakorzenienie w niej własnej dziejowości staje się możliwe rozumienie tego, co przynależy do podmiotu, jak i tego, co istnieje „obok” niego w innym podmiocie, obiekcie, czy sytuacji. Zapośredniczanie zatem rozumienia historii Uniwersytetu w Polsce w Ustawie 2.0 pozwala stwierdzić, że

Prawdziwy przedmiot historyczny nie jest przedmiotem, lecz jednością jednego i drugiego, stosunkiem, w którym istnieje zarówno rzeczywistość dziejów, jak rzeczywistość rozumienia historycznego. Adekwatna hermeneutyka wykazywałaby w samym rozumieniu rzeczywistość dziejów. Nazywam to, co w ten sposób postulowane, "dziejami efektywnymi". Rozumienie jest zgodne ze swą istotą procesem efektywnodziejowym ${ }^{17}$.

Ustawa 2.0. wyłania się zatem tutaj jako jedność rozumienia treści i formy, obiektu i działania w płaszczyźnie bycia i czasu, i dlatego powinna być postrzegana jako wyraz radykalnych oczekiwań społecznych, przeciwstawiając się stagnacji i samoograniczeniom, w którą popadają rzesze polskich uczonych. Dopełniająca się w tej płaszczyźnie dziejowość każdego podmiotu z osobna staje się efektywna w odniesieniu do sytuacji, w której się partycypuje i która służy osiągnięciu pewnej samowiedzy. Należy zatem żywić nadzieję, jak stwierdza S. Kemmis, że

...badania w działaniu zdołają zawrzeć w sobie nie tylko hermeneutykę Gadamerowską (efektywnodziejową świadomość), ale również możliwość badania granic języka i myślenia poprzez namysł nad tym, jak kształtowała je historia, uzus, służba różnego rodzaju interesom, które można odczytać w porządkach i konsekwencjach poszczególnych rodzajów pracy i życia politycznego ${ }^{18}$,

a także - należy dodać - etycznego, estetycznego, religijnego i politycznego, by dopełnić ogólnoludzką praxis.

Badania w działaniu, w swoich teoretycznych rozważaniach wskazują debatującym nie tylko kierunki działania, ale i sposoby jego realizacji. Niemniej zawierają one wytyczne, które w pełni nie da się zrealizować, bo trudno przewidzieć przebieg kreującej się sytuacji w obszarze efektywnodziejowej świadomości. Ten stan staje się jeszcze bardziej złożony, jeżeli uwzględni się fakt, że akt dopełniania się ogólnoludzkiej praxis ma charakter niemetodyczny ${ }^{19}$. I aby osłabić ten przypadkowy i nieusystematyzowany przebieg, działania podmiotów powinny przebiegać $\mathrm{w}$ przestrzeni phronesis, będącej mądrym i rozważnym działaniem w konkretnej praktycznie sytuacji. Rzeczowo i historycznie rzecz ujmując, badania w działaniu w400

\footnotetext{
17 H.-G. Gadamer, Prawda i metoda, s. 412.

18 S. Kemmis, Teoria krytyczna, s. 55.

19 D. Benner, Pedagogika ogólna, s. 24-32.
} 
swoim poznawczym ukierunkowaniu stanowią formę myślenia, której rzeczowość, rzetelność i autentyczność ma odsłonić prawdę tego, do czego się odnosi.

Jaką zatem rolę należy przypisać phronesis w badaniach w działaniu? W ramach wprowadzenia w tematykę należy zauważyć, iż zanim badania w działaniu uzyskały powyższy status, to w swojej ewolucji, na początku pierwszej połowy dwudziestego wieku, nie zyskały aprobaty uczonych, ponieważ nie spełniały kryteriów metodologicznych ${ }^{20}$. W. Carr w nawiązaniu do Nevitta Sanforda pisze: „Niedopełnienie metodologicznych wymagań pozytywizmu przyczyniło się do marginalizacji i rychłego upadku badań w działaniu”"21. Ich nowy ogląd i praktyczne zastosowanie dokonały się za sprawą angielskich uczonych, którzy położyli nacisk na ich aspekt jakościowy w metodologii w ujęciu interpretatywnym, co pozwoliło usytuować ich użyteczność w kreowanej praktyką społeczno-kulturowej przestrzeni przez obecnych w niej działających aktorów. Istotą zatem tak pojętych badań miał być rozwój praktyki, co miało się przekładać na wzrost efektywności tego, na co były ukierunkowane. Pomimo wprowadzenia nowych kontekstów do istoty badań w działaniu, problem z metodologią nie został rozwiązany. Pewnych rozwiązań poszukiwali edukatorzy, ale wielu uczonych uznało, że nie spełniają one kryteriów naukowego myślenia ${ }^{22}$. Temat okazał się jeszcze bardziej złożony, kiedy badania w działaniu znalazły swój nowy ogląd w rozważaniach wspomnianego już H.-G. Gadamera - należącego do rzecznika hermeneutyki, a także kiedy wielu uczonych stwierdziło, że metody stosowane przez tę dziedzinę poznania są mało naukowe ${ }^{23}$. Ten stan rzeczy wydaje się wynikać z błędnego utożsamiania hermeneutyki z postmodernizmem przez realistów, o czym przekonująco pisze Andrzej Przełębski ${ }^{24}$. Z innej strony warto zauważyć, skoro hermeneutyka nie wypracowała własnych metod badawczych i jeśli dlatego nie przyznaje się jej statusu naukowości, to również nienaukowa powinna być historia czy pedagogika z uwagi na ich praktycznie stosowany charakter poznania. W każdym razie hermeneutykę należy postrzegać jako formę poznania racjonalnego, która nie podpada pod logikę formalną i tradycyjnie pojmowaną metodologię. Za właściwą formę wskazywanej tutaj racjonalności należy uznać - idąc tropem H.-G. Gadamera - phronesis. Z tej to przyczyny należy sięgnąć do źródeł tego pojęcia, a najlepiej do Etyki nikomachejskiej Arystotelesa ${ }^{25}$, w której filozof wskazuje trzy rodzaje mądrości i tym

${ }^{20}$ W. Carr, Filozofia, metodologia, s. 31-38.

21 Tamże, s. 32.

22 J. Elliott, Action Research for Educational Change, Milton Keynes 1991.

23 J. Grondin, Wprowadzenie do hermeneutyki filozoficznej, przekł. L. Łysień, Kraków 2007.

24 A. Przełębski, Filozofia hermeneutyki nie jest postmodernizmem, [w:] Tenże, Dlaczego Polska jest wartością. Wprowadzenie do hermeneutycznej filozofii polityki, Poznań 2013.

${ }_{25}$ Arystoteles, Etyka nikomachejska, przekł. D. Gromska, Warszawa 2012. 
samym trzy rodzaje racjonalności, a mianowicie: sophia, techné i phronesis. I tak, sophia jako myślenie teoretyczne (theoria) dotyczy tego, co niezmienne. $\mathrm{Z}$ kolei techné obejmuje myślenie podległe temu, co jest wytwarzane (poíesis) i oparte na pewnych regułach, zasadach. Natomiast phronesis jako rozsądek czy mądrość praktyczna odzwierciedla się w życiu codziennym jako forma namysłu, odnoszącego się do działań określanych mianem praxis. Ten rodzaj wiedzy jest oparty na doświadczeniach i nawykach, a będąc przy tym powiązany z wiedzą moralną, staje się podstawą dla podejmowania słusznych i prawidłowych decyzji, działań. Kumulowana przez phronesis wiedza nie ma charakteru niezmiennego (sophia), ani też technicznego (technê); ma wymiar sytuacyjny i refleksyjny, a skoro oparta jest na doświadczeniach i nawykach, to już teraz możemy przyjąć, o czym jeszcze będzie mowa, że mamy tutaj do czynienia z pojawianiem się dyspozycji (umiejętność, plan czegoś), które są kształtowane w trakcie praktyki; a więc jest formą ludzkich działań (praxis) - formą ludzkiej koegzystencji, na którą składają się, zasygnalizowane już: polityka, ekonomia, etyka, estetyka, pedagogika i religia ${ }^{26}$.

Wiedza, do której odnosi się phronesis - stwierdza Michał Januszkiewicz - to zatem wiedza, która dotyczy rzeczy zmiennych (tych, które mogą być inaczej - mówiąc językiem Arystotelesa), a więc wiedza nie dająca pewności i która prowadzi przez to do podejmowania działań, skutkujących nie zawsze maksymalnie preferowanymi rezultatami bądź też rezultatami, które przynajmniej dają się przewidzieć na podstawie rachunku prawdopodobieństwa ${ }^{27}$.

Phronesis w swoim procesie poznawczego uogólniania nie jest dedukcyjną formą rozumowania, wskazującą na konkretne środki, za pomocą których osiąga się określone cele; nie jest to zatem myślenie i działania techniczne (techné) poietycznie zinstrumentalizowane. Jest to zatem taka forma myślenia i działania, w której - idąc tropem Arystotelesa - intelekt wraz z moralnością stanowią formę ludzkiej praktyki, dzięki której człowiek działa właściwie w określonym miejscu i czasie. Działania właściwe łączy zatem phronesis z działaniem natury etycznej, które ma prowadzić do jego zrozumienia, w centrum którego to rozumienia, a konkretnie rozumowania W. Carr sytuuje: namysł, refleksję i osąd. Te trzy wyznaczniki rozumowania, wpisując się $\mathrm{w}$ rozumienie sytuacji, powinny pogłębić wgląd w wykładnię Ustawy 2.0. Dlatego należy zapytać, jak należy rozumieć te trzy elementy rozumowania? W. Carr pisze:

„Namysł" jest konieczny, gdyż phronesis w przeciwieństwie do techné nie stanowi formy rozumowania, jak osiągnąć określony cel, lecz pełen namysłu proces, w którym

${ }^{26}$ D. Benner, Pedagogika ogólna, s. 33-52.

27 M. Januszkiewicz, Phronesis: racjonalność hermeneutyczna, Przestrzenie Teorii, 2016, 25, s. 85. 
zarówno środki, jak i cele pozostają otwarte na dyskusję. Rozumowanie to jest refleksyjne, ponieważ środki zawsze zostają przekształcone w toku refleksji o celach, a cele - w toku refleksji dotyczącej środków. Osąd zaś stanowi uzasadniony element phronesis, gdyż prowadzi do racjonalnej decyzji dotyczącej tego, jak postąpić w konkretnej sytuacji. Decyzji tej można bronić dyskursywnie, a także uzasadnić ją jako adekwatną do okoliczności, w których się ją podejmuje ${ }^{28}$.

Namysł, refleksja i osąd kształtując rozumienie wpisujące się w phronesis, czynią dyskusję otwartą na refleksję o środkach i celach, dzięki czemu wyłaniające się w wyniku ich stosowania decyzje podlegają racjonalizacji. Racjonalizacja w tej formie wymusza inne podejście do metodologii. Ponieważ phronesis wpisując się w badania w działaniu, wskazuje na jej niemetodologiczny charakter, który jeśli się pojawia, to sprawia, że praxis myślenia i działania zostaje przekształcony w techné. Powyższy stan rzeczy, zdaniem G.-H. Gadamera ${ }^{29}$, wynika z nastawienia współczesnej nauki na rozwój i kształtowanie metod poznania, które przyczyniły się do wypatrzenia aktów rozumienia w procesach naukowego poznania. W. Carr pisze:

Gadamer wyraźnie pokazuje, że dążenie do osiągnięcia czysto racjonalnego rozumienia jest zwodnicze, ludzkie rozumienie nigdy nie jest po prostu "dane" w postrzeżeniu czy obserwacji, lecz jest zawsze „uprzedzone” przez interpretacyjny element, który określa sposób rozumienia owych postrzeżeń i przekonań. Ponadto akt rozumienia jest zawsze aktem interpretacji oraz ma nieuchronnie charakter historyczny ${ }^{30}$.

Phronesis - w takiej sytuacji - odnosząc się poprzez praxis do tego, w czym działa, odnosi się do wskazanych trzech składowych badań w działaniu; zawiera zatem i w sobie rozumienia, a przy tym interpretację, i z tej przyczyny wpisuje się $\mathrm{w}$ istotę hermeneutyki ${ }^{31}$. Poprzez rozumienie i interpretacje dopełnia się rozpoznanie sytuacji, w której podmiot się znajduje, a wraz z nim dopełnia się właściwy jemu akt samorozumienia. W odniesieniu do Ustawy 2.0 należy stwierdzić, że interpretacja, która określa sposób rozumienia, jest ciągłym procesem, w którym - uobecniające się treści zawarte w tej Ustawie będą rozumiane na wiele sposobów. Zawarty w nich namysł, refleksja i osąd będą przebiegać od tego co ogólne, do tego co szczególne i zwrotnie - od tego co szczególne, do tego co ogólne. Toteż zwrotność tych działań będzie sprowadzać sens praxis do tego, że nie tyle jak coś się robi, ale co się robi. W Ustawie 2.0, w jej strukturach warunkujących działania będzie w konsekwencji dopełniać się sens ludzkiego jestestwa jako istoty stającej się, doświadczającej siebie poprzez praxis środowiska, w którym będzie realizowana interesująca

${ }^{28}$ W. Carr, Filozofia, metodologia, s. 36.

${ }^{29}$ H.-G. Gadamer, Hermeneutics and Social Science, Cultural Hermeneutics, 1975, 2, s. 312.

${ }^{30}$ W. Carr, Filozofia, metodologia, s. 38-39.

${ }^{31}$ M. Januszkiewicz, Phronesis, s. 85. 
nas Ustawa. Można zatem powiedzieć, że phronesis kreuje miejsca (modus realizacji Ustawy 2.0) w doświadczanej przez podmiot praktyce, w której zespala się jego teraźniejsza obecność z tym, co tę obecność historycznie warunkuje, przyczyniając się do uczasowienia refleksji - jakby powiedział Martin Heidegger $^{32}$ - warunkującej interpretację jako źródło możliwego rozumienia swojego miejsca w praxis (modus tej Ustawy). Oznacza to, że realizacja tej Ustawy - poprzez badania $\mathrm{w}$ działaniu, normalizowane ideą phronesis - będzie ściśle zależna od funkcjonowania środowisk naukowych i artystycznych w naukowych instytucjach, które nieuchronnie będą prowadzić do efektywnodziejowej świadomości w akcie samozrozumienia. Procesualny charakter tego samozrozumienia stanowi efekt działania, a więc i praktyki, w której dzianie się dziejów powinno przyczynić się do bardziej efektywnego funkcjonowania w nim jednostek, które istocząc się w stawaniu się podmiotami, co w konsekwencji - idąc tropem M. Heideggera ${ }^{33}$ na temat poręczności narzędzi - powinno pozwolić jej uczestnikom widzieć i rozumieć "coś jako coś” i aby interpretować to „coś”, „po to ażeby”. Toteż użycie czegoś jako narzędzia w działaniu należy wiązać z rozumieniem tego, co należy zrobić i jaką należy podjąć decyzję, aby była najbardziej stosowna i użyteczna. Każda bowiem decyzja w swoim działaniu wyznaczona jest przez praktykę, przez faktyczność życia (praxis), w którym „....wszystko, co rozumienie przekazuje, jest przekazywane wraz z nami" ${ }^{34}$. Ustawa 2.0 staje się zatem dla jej prawodawców i wykonawców zwierciadłem w drodze do zrozumienia siebie, w której każdy podmiot na swój własny i zindywidualizowany sposób doświadcza siebie w swoistym działaniu, którego praxis pozwala każdej jednostce z osobna kształtować i ujawniać wypracowane oraz wdrażane w życie społeczne zasady myślenia i działania ludzkiej koegzystencji afirmujące sens niepowtarzalnej egzystencji.

Jak można przypuszczać, dookreślenie istoty badań w działaniu, które w swojej strukturze mają stanowić wykładnię Ustawy 2.0, w dużej mierze może przysłużyć się jej wdrażaniu w życie i to zgodnemu z oczekiwaniami wszystkich stron zainteresowanych, to jest pracownikom Ministerstwa Nauki i Szkolnictwa Wyższego, władz uczelni wyższych w Polsce i pracowników nauki oraz sztuki. Jednak, mając na uwadze naukowy charakter tej Ustawy i możliwość jej na przykład upolitycznienia, to wskazane byłoby dopełnienie badań w działaniu ideą ogólnoludzkiej praxis.

Próba przybliżenia wskazanej tutaj idei będzie opierać się na poglądach D. Bennera ${ }^{35}$. Myśliciel ten zastanawiając się nad podstawami myślenia

\footnotetext{
${ }^{32}$ M. Heidegger, Rozmowy na polnej drodze, przekł. J. Mizera, Warszawa 2004, s. 116 i n.

${ }_{33}$ M. Heidegger, Bycie i czas, s. 218-227.

${ }^{34}$ H.-G. Gadamer, Prawda i metoda, s. 110.

${ }^{35}$ D. Benner, Pedagogika ogólna, s. 24-25.
} 
i działania w sferze wychowania, odniósł się do różnych obszarów pedagogicznej praxis, których usystematyzowanie i scalenie będzie odwzorowywać się $w$ innych formach ludzkiego działania, stanowiących tutaj całokształt ludzkiej praxis. Nawiązując do sfery i ludzkich wytworów kultury w aspektach historyczno-dziejowych, stwierdza, że na ideę ludzkiej praxis - dzięki której człowiek nadaje sobie określeń i staje się istotą ludzką, realizującą się w dążeniu do osiągnięcia samospełnienia - składają się trzy płaszczyzny ludzkiego istnienia, a mianowicie: koegzystencjalna, egzystencjalna i inegzystencjalna. W skład ludzkiej koegzystencji wchodzą takie kategorie, jak: ekonomia, polityka, etyka, estetyka, religia i pedagogika. $\mathrm{W}$ tym temacie możemy przeczytać:

Jak wynika z doświadczeń historycznych współżycie międzyludzkie, czyli ludzką „koegzystencję", da się w zadawalający sposób opisać za pomocą sześciu głównych kategorii. Człowiek przez pracę, eksploatację i kultywację przyrody musi zabezpieczyć sobie podstawę życiową i ją zachować (ekonomia); musi zastanowić się nad normami i regułami porozumienia międzyludzkiego, rozwijać je i respektować (etyka); musi projektować przyszłość społeczną i ją kształtować (polityka); za pomocą przedstawienia estetycznego (sztuka) człowiek wykracza poza swoją teraźniejszość i zastanawia się nad problemem przemijania innych ludzi i własnej śmierci (religia). Do pracy, etyki, polityki, sztuki i religii dołącza się wychowanie jako szósta kategoria. Człowiek zajmuje określone miejsce między pokoleniami: jest wychowywany przez osoby należące do poprzedniego pokolenia i sam będzie kiedyś wychowywał członków pokolenia, które po nim nadejdzie ${ }^{36}$.

Istotne dla tej sfery ludzkiego istnienia jest to, aby nie dopuścić do zdominowania przez jedną $\mathrm{z}$ tych form pozostałych. Dlatego tak ważne jest dookreślenie wykładni Ustawy 2.0. Jej wdrażanie w życie nie może stać się formą technicznego działania; musi podlegać rozumowaniu wpisującego się $\mathrm{w}$ osnowę phronesis. Stanie się to możliwe, jeżeli idee związane z rozumowaniem będą wdrażane $\mathrm{w}$ drugą płaszczyznę ludzkiego istnienia ogólnoludzkiej praxis, to jest egzystencjalną w sposób ucieleśniony, wolny, historyczny i werbalny ${ }^{37}$ (patrz ryc. 1). Działania tego typu wynikają z dwóch faktów. Po pierwsze, człowiek z natury jest istotą niedoskonałą, a po drugie - obarczoną wolnością. Oznacza to, że te cztery egzystencjalne wskaźniki ludzkiej praxis, w kontekście polityki, ekonomii (pracy), etyki, estetyki (sztuki) religii i pedagogiki, bazując na wolności, umożliwiają każdej jednostce przezwyciężanie własnych niedoskonałości. D. Benner w tym temacie stwierdza:

... cielesność, dzięki której jesteśmy zdolni do prerefleksyjnego odbierania wrażeń zmysłowych i ich artykułowania, wolność, która umożliwia nam dokonywanie wy-

${ }^{36}$ Tamże, s. 27.

37 Tamże, s. 42 in. 
borów wykraczających poza granice wolności zdeterminowanej fatalistycznie lub woluntarystycznie, historyczność, która nie skazuje człowieka ani na bycie ofiarą historii, ani jej panem, lecz zleca mu do wypełnienia zadanie bycia odpowiedzialnym współtwórcą jej biegu, oraz werbalność, która nie zmusza nas do lustrzanego odzwierciedlania świata ani do jego nominalistycznego opisywania, lecz zapewnia możliwość doświadczania go i komunikowania się z innymi na temat naszych doświadczeń, nie tworzą między sobą żadnego organicznego czy teologicznego porządku ${ }^{38}$.

Brak organicznego czy teologicznego porządku prowadzi nas do trzeciego elementu struktury praxis - do inegzystencji, na którą składają się zasady myślenia i działania politycznego, ekonomicznego, etycznego, estetycznego, religijnego i pedagogicznego (patrz ryc. 1). Zasady myślenia i działania należy traktować jako mechanizmy ukierunkowujące działania, prowadzące do poszukiwania swojego powołania, przekładającego się ostatecznie na nada-

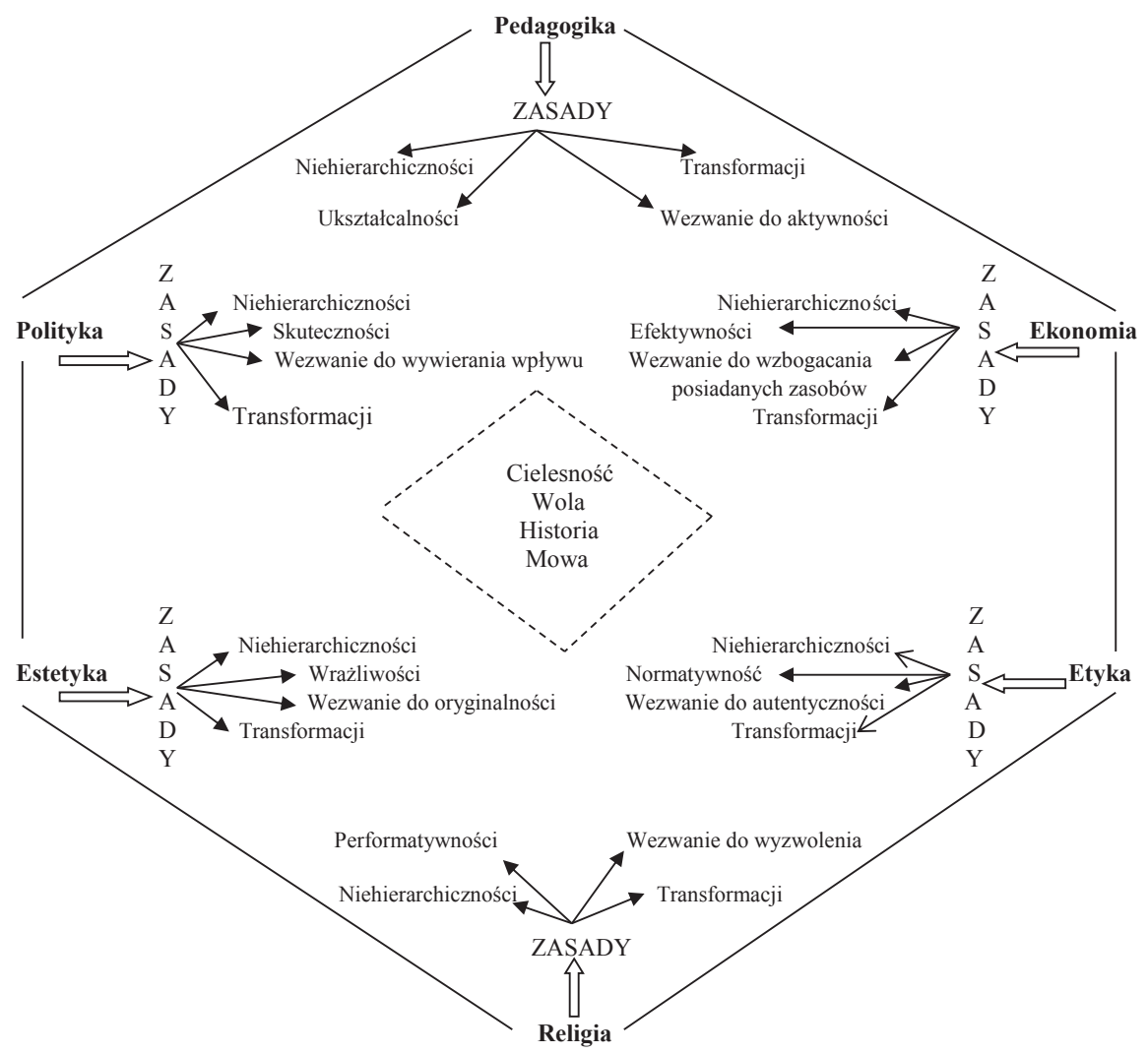

Ryc. 1. Struktura całokształtu ludzkiej praxis

38 Tamże, s. 50. 
wanie sobie określenia. Tam samym, zindywidualizowane praxis we współpracy z innymi zindywidualizowanymi podmiotami będą nadawać ostateczny sens temu, do czego się odnoszą.

D. Benner, mając na uwadze płaszczyznę egzystencjalną i koegzystencjalną pedagogicznej praxis, wyróżnił dwie konstytutywne zasady myślenia i działania pedagogicznego oraz dwie regulatywne zasady myślenia i działania pedagogicznego ${ }^{39}$. Wśród pierwszych wyróżnił ukształcalnośći wezwanie do aktywności własnej, a do drugich zaliczył transformację społecznych determinacji na pedagogiczne oraz niehierarchiczny i ateleologiczny porządek całokształtu ludzkiej praxis. Zasada ukształcalności wskazuje na afirmacyjną zdolność człowieka do współpracy z innymi i dopełniania w sobie indywidualnego powołania. Zasada wzywająca do własnej aktywności oznacza bycie wezwanym do działania przez inny podmiot. Z kolei, zasada transformacji oddziaływań społecznych na pedagogiczne jest regulowana przez zasadę wezwania do własnej aktywności, „.... aby przeciwdziałać degradowaniu pedagogicznej praxis do roli posługaczki wykonującej polecenia społeczne adresowane do systemu wychowania i kształcenia" ${ }^{40}$. I w końcu, zasada dotycząca niehierarchicznego układu całokształtu ludzkiego praxis ma wskazywać na ukształcalność prowadzącą do równego współdziałania wszystkich form koegzystencjalnych ludzkiego praxis. W ten sposób zasady w swojej inegzystencji ukierunkowują egzystencjalne struktury ludzkiego działania w obszarach koegzystencjalnych, co ostatecznie wpływa na nadawanie sobie znaczenia. Znaczenie w swojej praktyce dokonuje się zawsze w jakimś stematyzowanym kulturowo i historycznie polu, którego treści i znaczenia podlegają społecznym negocjacjom. Regulatywny, a więc społeczny charakter tych negocjacji warunkuje, a więc i reguluje to co konstytutywne, co pozwala nam traktować projekt Ustawy 2.0 jako pole, w którym urzeczowiane życie społeczne będzie przekładać się na indywidualne kreowanie własnych działań przez podmioty $\mathrm{w}$ tym projekcie uczestniczące.

Ponieważ wskazane przez D. Bennera zasady myślenia i działania pedagogicznego w swojej koegzystencji mają współdziałać z innymi formami myślenia i działania koegzystencjalnego ogólnoludzkiego praxis, toteż należałoby zastanowić się nad pozostałymi zasadami, aby mieć na uwadze ogólnoludzkie uniwersum wpisujące się w kształtowanie istoty ludzkiej. Analiza zasad pedagogicznej praxis pozwala doszukiwać się pewnych uspójnień w myśleniu i działaniu poszczególnych form koegzystencjalnych. Po pierw-

\footnotetext{
39 Tamże, s. 69-141.

40 Tamże, s. 140.
} 
sze, należy przyjąć, że zasady regulatywne będą przystawać do siebie w jednorodnej strukturze tegoż myślenia i działania. Po drugie, różne będą zatem zasady konstytutywne. I tak, zasada niehierarchicznego i ateleologicznego porządku całokształtu ludzkiej praxis musi $\mathrm{w}$ niezmiennej formule występować we wszystkich wyróżnionych kategoriach koegzystencjalnych, ponieważ żadna $\mathrm{z}$ tych kategorii nie może rościć sobie prawa do ustanawiania swojej władzy ponad innymi. Z kolei zasada, która w pedagogicznej praxis wskazuje na transformację oddziaływań społecznych na pedagogiczne, pozwala sądzić, że transformacje społecznych oddziaływań będą ukierunkowane $\mathrm{w}$ zależności od koegzystencjalnej praxis albo na polityczne, albo na ekonomiczne i tak dalej. Jeżeli chodzi o zasady konstytutywne, mamy tutaj do czynienia z sytuacją bardziej złożoną. Zatem, próba wskazania tych zasad wymaga głębszych przemyśleń wspartych wiedzą wywiedzioną z historii poszczególnych dyscyplin. Nie wdając się w niniejszej wypowiedzi w głębsze analizy, niejako sygnalizacyjnie wskażę te zasady, które w dalszej kolejności powinny podlegać nieustannej weryfikacji. Przede wszystkim, opierając się na zasadach konstytutywnych pedagogicznej praxis, warto zachować ich układ, to jest taki, że pierwsze z nich wskazuje na określone formuły myślenia i działania, a drugie stanowią „wezwanie do". I tak, w przypadku polityki należałoby uznać takie zasady, jak skuteczność i wezwanie do wywierania wpływu. Z władzą, jej sprawowaniem i jej efektami wiąże się kształtowanie jednostek, które w swoim działaniu oraz myśleniu powinno być skuteczne, a skuteczność stanie się możliwa dzięki wpływaniu, oddziaływaniu, zapośredniczaniu się. Co się tyczy zasad myślenia i działania ekonomicznego, warto ukierunkować swoją propozycję na efektywność i wezwanie do wzbogacania posiadanych zasobów. Oznacza to, że każda jednostka wyposażona jest $\mathrm{w}$ pewne predyspozycje, zdolności, zdatności i dlatego nadawanie sobie określenia przez poszczególne jednostki będzie zależne od tych predyspozycji, ale też ich przekształcanie oraz wzbogacanie powinno dokonywać się za sprawą działań efektywnych i tym samym je wzbogacających. Kolejne zasady wiążemy z etyką i tutaj warto wyróżnić jako zasady normatywność oraz wezwanie do własnej autentyczności. W tym przypadku nikogo nie powinno dziwić, że myślenie i działania etyczne ukierunkowane są na normatywność oraz na fakt wzywający jednostki do własnej autentyczności ${ }^{41}$. Następnymi zasadami wpisującymi się teraz w estetykę, są wrażliwość i wezwanie do oryginalności. Wiąże się z nimi przede wszystkim emocjonalny wymiar bycia człowiekiem, którego wrażliwość pozwala przezwyciężać własny egoizm, dostrzegać niecodzienność w codzienności i stawać się kimś niepowtarzalnym. Co się zaś tyczy ostatniej kategorii koegzystencjalnej, czyli religii, war-

${ }^{41}$ Ch. Taylor, Etyka autentyczności, przekł. A. Pawelec, Kraków 2002. 
to wskazać tutaj takie zasady, jakie można by wiązać z performatywnością, a konkretnie - z performancem oraz wezwaniem do wyzwolenia. $\mathrm{W}$ pierwszym przypadku, idąc tropem N. Luhmanna ${ }^{42}$, należy mieć na uwadze takie działania, w których religia współpracuje z innymi kategoriami koegzystencjalnej praxis, aby dopomóc im $\mathrm{w}$ osiąganiu celów, kiedy same nie potrafią rozwiązywać problemów, zadań i tym podobnych. Z kolei, wezwanie do wyzwolenia - w swojej religijnej transcendencji dotyczącej bardziej formy niż treści - pozwala elementom, obiektom, faktom i tym podobnej rzeczywistości świeckiej przekraczać jej ograniczenia i funkcjonować w sposób autonomiczny, sprawczy. W ten sposób podmiot w swojej niedoskonałości, w sposób sprawczy przekracza siebie i nadaje sobie nowe znaczenia.

Co zatem wynika z prowadzonych tutaj rozważań? Na początku można przyjąć, że efekty wdrażanej Ustawy będą zależne od wzajemnej współpracy stron zainteresowanych i kształtującej się w tym obszarze efektywnodziejowej świadomości. Ukształcanie tej świadomości, wpisując się w badania w działaniu, będzie zależne od otwartości samych zainteresowanych na osiągnięcie konsensusu, który zadowoliłby wszystkie strony realizujące wytyczne tej Ustawy. Przy czym, osiągnięcie kompromisu, który powinien służyć nauce, a wiec bardziej ludziom nauki, niż zbiurokratyzowanym formom tej Ustawy, stanie się bardziej realne, jeżeli sens tej Ustawy stanie się podległy badaniom w działaniu. Tego typu wytyczna, poprzez dialogiczny charakter badań w działaniu, powinna nadać treściom, jak i formie ustawy bardziej refleksyjny, oglądowy i kreatywny wymiar. Wymiar ten osiągnie się, jeżeli badania $\mathrm{w}$ działaniu podporządkuje się wiedzy nawiązującej w swojej praktyce do phronesis. Ukierunkowanie działań na phronesis jest dlatego ważne, kluczowe, ponieważ ta forma wiedzy w swojej metodologii uniemożliwia podporządkowanie praktyki techné zinstrumentalizowaniu tej Ustawy. Co więcej, aby Ustawa 2.0 nie podlegała upolitycznieniu, elementy struktury badań w działaniu, na którą składają się namysł, refleksja i osąd, powinno odnosić się do idei ogólnoludzkiej praxis. Odnoszenie to w swojej konsekwencji powinno stanowić źródło wzrostu autozrozumienia.

Zatem, uwzględnienie wskazanych elementów wpisujących się w badania w działaniu powinny - jak się zdaje - przyczynić się do wzrostu świadomości uczonych i większego zaangażowania $\mathrm{z}$ ich strony $\mathrm{w}$ działania na rzecz rozwoju własnego i nauki.

\section{BIBLIOGRAFIA}

Arystoteles, Etyka nikomachejska, przekł. D. Gromska, Wydawnictwo Naukowe PWN, Warszawa 2012.

${ }^{42}$ N. Luhmann, The Differentiation of Society, New York 1982. 
Benner D., Pedagogika ogólna: Wprowadzenie do myślenia i działania pedagogicznego w ujęciu systemowym i historyczno-problemowym, przekł. D. Stępkowski, Wydawnictwo Uniwersytetu Kardynała Stefana Wyszyńskiego, Warszawa 2015.

Carr W., Filozofia, metodologia i badania w działaniu, przekł. K. Liszka, [w:] Badania w działaniu. Pedagogika i antropologia zaangażowane, red. H. Červinkowá, B.D. Gołębniak, Wydawnictwo Naukowe Dolnośląskiej Szkoły Wyższej, Wrocław 2010.

Cicmil S., Gaggiotti H., Who cares about project deadlines? a processual relational perspective on problems with information sharing in project environments, International Journal of Knowledge Management Studies, 2009, 3, 3-4.

Elliott J., Action Research for Educational Change, Open University Press, Milton Keynes 1991.

Gadamer H.-G., Hermeneutics and Social Science, Cultural Hermeneutics, 1975, 2.

Gadamer H.-G., Practical Philosophy as a Model of the Human Science, Research in Phenomenology, 1980, 9 .

Gadamer H.-G., Prawda i metoda. Zarys hermeneutyki filozoficznej, przekł. B. Baran, Wydawnictwo Naukowe PWN, Warszawa 2004.

Grondin J., Wprowadzenie do hermeneutyki filozoficznej, przekł. L. Łysień, Wydawnictwo WAM, Kraków 2007.

Habermas J., Teoria dziatania komunikacyjnego, t. 1, przekł. A.M. Kaniowski, Wydawnictwo Naukowe PWN, Warszawa 1999.

Habermas J., Teoria dziatania komunikacyjnego, t. 2, przekł. A.M. Kaniowski, Wydawnictwo Naukowe PWN, Warszawa 2002.

Habermas J., Faktyczność i obowiąywanie. Teoria dyskursu wobec zagadnień prawa i demokratycznego państwa prawnego, przekł. A. Romaniuk, Wydawnictwo Naukowe Scholar, Warszawa 2005.

Habermas J., Filozoficzny dyskurs nowoczesności, przekł. M. Łukaszewicz, Wydawnictwo Universitas, Kraków 2005.

Heidegger M., Bycie i czas, przekł. B. Baran, Wydawnictwo Naukowe PWN, Warszawa 1994.

Heidegger M., Rozmowy na polnej drodze, przekł. J. Mizera, Wydawnictwo KR, Warszawa 2004.

Januszkiewicz M., Phronesis: racjonalność hermeneutyczna, Przestrzenie Teorii, 2016, 25.

Kemmis S., Teoria krytyczna i uczestniczace badania w działaniu, przekł. K. Liszka, [w:] Badania w dziataniu. Pedagogika i antropologia zaangażowane, red. H. Červinkowá, B.D. Gołębniak, Wydawnictwo Naukowe Dolnośląskiej Szkoły Wyższej, Wrocław 2010.

Kemmis S., McTaggart R., The Action Research Planner, Deakin University Press, Geelong 1988.

Luhmann N., The Differentiation of Society, Columbia University Press, New York 1982.

Przełębski A., Filozofia hermeneutyki nie jest postmodernizmem, [w:] Tenże, Dlaczego Polska jest wartością. Wprowadzenie do hermeneutycznej filozofii polityki, Wydawnictwo Poznańskie, Poznań 2013.

Taylor Ch., Etyka autentyczności, przekł. A. Pawelec, Wydawnictwo Znak, Kraków 2002.

Sharp G., Od dyktatury do demokracji. Drogi do wolności, przekł. A. Karolak, Fundacja A. Einsteina, Warszawa 2013. 
